\section{Hard Words about Pollution}

Dr E. F. Schumacher, economic adviser to the Coal Board, was brave enough last week to attack the safety standards in nuclear power stations. In a speech to the conference of the National Society for Clean Air (Nature, 216, 219; 1967) Dr Schumacher claimed that nuclear power stations would gradually contaminate the environment, by "silently leaking radioactivity into the ground". The increasing use of nuclear fuel would add to the dangers of accidents in transport, and what would be done with nuclear power stations when they came to the end of their active lives? Dr Schumacher pictured them standing idle all over the country as mute witnesses to the folly of allowing economic criteria to dictate policy. No insurance company, he added, would take on third party risks for nuclear power stations.

The spokesmen for the Ministry of Power and the Electricity Board responded with the alacrity born of long experience of the Coal Board. Mr Peter Williamson, for the CEGB, managed to get his reply in first, by responding to Dr Schumacher's speech at the conference. Reactors once out of use would be sealed up and covered up with a mound of earth, he said, and would be no danger. Accident-proof containers have been designed for the transport of dangerous materials, and insurance companies did accept the third party risks for nuclear stations. The Ministry of Power was slower to react, but no less decisive. Dr Schumacher's statements, the ministry said, "are so inaccurate that they cannot be regarded as a serious contribution to any discussion of the subject". External radiation from power stations, it added, is virtually non-existent.

Later, Dr Schumacher claimed that his remarks had been misinterpreted. He has no criticism of the way in which dangerous materials are handled at the moment, and regrets that certain points used to illustrate the theme of his address should have been taken as an attack on standards of public safety. The caution Dr Schumacher made was against too much emphasis on economics. Too often the cheapest production methods for commodities are used without enough consideration of the human factors involved. A massive increase in nuclear power installations might not be matched by a greater knowledge of how to protect man from dangerous radiation.

\section{Know your Joneses}

THE amount a country spends on research and development is probably the most confusing index of economic performance ever devised. Even so, British ministers will doubtless feel encouraged when they read a recent report prepared by the Organisation for Economic Co-operation and Development (The Overall Level and Structures of $R$ and $D$ Efforts in OECD Member Countries, OECD, 9s.). The fact that Britain spends far more than other European countries on research is likely to be regarded by British supporters as a further reason why Britain should be admitted to the Common Market. But it would be equally easy to say that a large research budget, combined with a stagnant economy, merely emphasizes how loth Britain is to change.

The United States, of course, leads the field by a very substantial margin. It spends more both in real terms-more than $\$ 21,000$ million-and as a proportion of gross national product-3.4 per cent. Great Britain spends $\$ 2,160$ million, $2 \cdot 3$ per cent of the GNP, while France and Germany manage $\$ 1,299$ million $(1 \cdot 6$ per cent) and $\$ 1,436$ million $(1 \cdot 4$ per cent) respectively. Other countries of the EEC trail well down the field; Italy spends only 0.6 per cent of the GNP on research and development. The Netherlands, on the other hand, spends 1.9 per cent and Sweden $1 \cdot 4$ per cent.

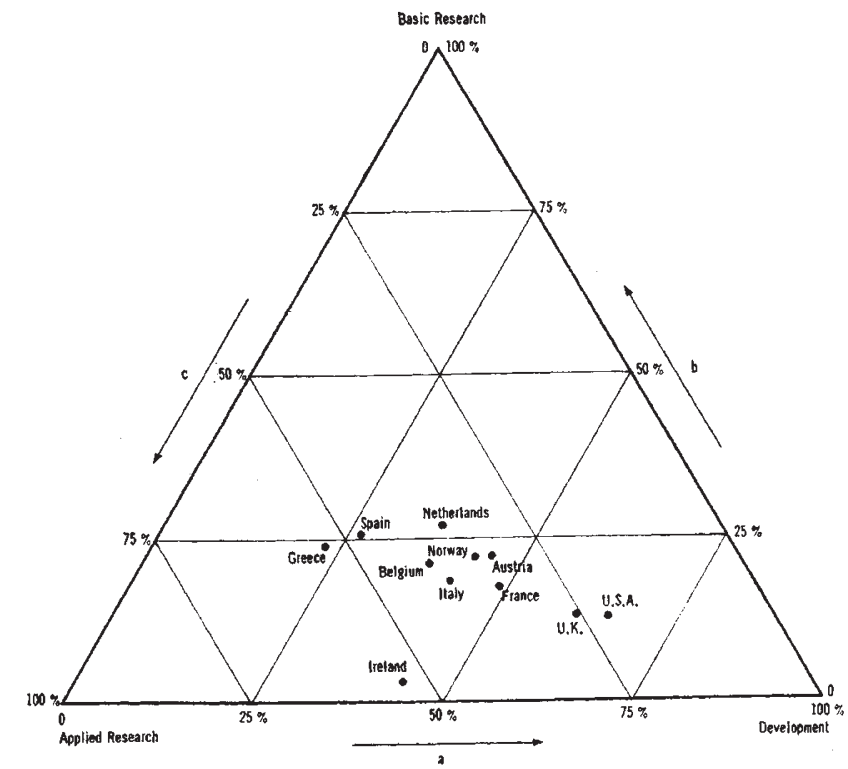

This diagram, after the style familiar to metallurgists and physical chemists, shows the amounts spent by various countries on basic research, applied research and development.

The report does nothing to encourage illusions of the value of these figures. "International comparisons of GNP percentages are not good yardsticks for science planning. Such an evaluation can be made only in the light of the research and development aims a country sets itself, some of which are more costly to realize than others." For this reason the report makes a useful analysis of the proportions spent on different areas of research. About two-thirds of the expenditure in the United States, for instance, is devoted to nuclear, space and defence research and development. France spends 45 per cent of her total in these three fields, and Britain just under 40 per cent. According to the figures, Japan spends nothing at all on these activities.

The United States employs as many qualified scientists, engineers and technicians as the rest of the OECD countries put together. A full-time equivalent of 700,000 qualified people is estimated for the United

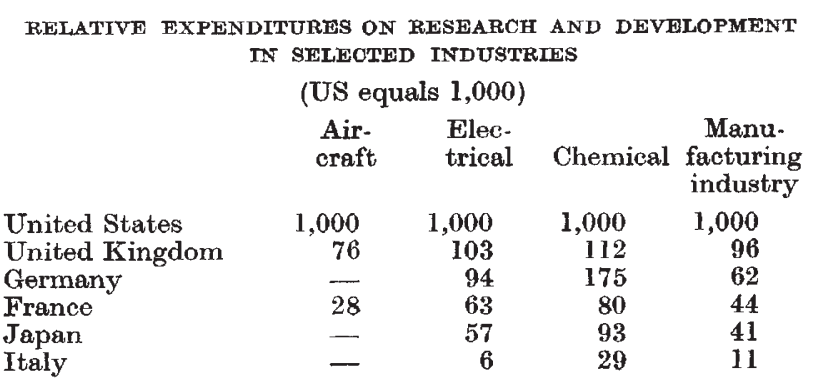

